\title{
Geographical distribution of trace elements (selenium, zinc, iron, copper) and case fatality rate of COVID-19: a national analysis across conterminous USA
}

\author{
Ying Chen $\cdot$ Zheng Feei Ma $\cdot$ Dahai Yu $\cdot$ Zifei Jiang $\cdot$ Bo Wang $\cdot$ \\ Linxi Yuan 1 (1)
}

Received: 29 July 2021 / Accepted: 9 January 2022 / Published online: 30 January 2022

(C) The Author(s), under exclusive licence to Springer Nature B.V. 2022

\begin{abstract}
Severe outcome particularly death is the largest burden of COVID-19. Clinical observations showed preliminary data that deficiency in certain trace elements, essential for the normal activity of immune system, may be associated with worse COVID-19 outcome. Relevant study of environmental epidemiology has yet to be explored. We investigated the geographical association between concentrations of $\mathrm{Se}, \mathrm{Zn}, \mathrm{Fe}$ and $\mathrm{Cu}$ in surface soils and case fatality rate of COVID-19 in USA. Two sets of database, including epidemiological data of COVID19 (including case fatality rate, from the University of John Hopkinson) and geochemical concentration
\end{abstract}

Supplementary Information The online version contains supplementary material available at https://doi. org/10.1007/s10653-022-01204-0.

Y. Chen

Wisdom Lake Academy of Pharmacy, Xi' an Jiaotong-

Liverpool University, Suzhou 215123, China

Z. F. Ma · Z. Jiang $\cdot$ L. Yuan $(\bowtie)$

Department of Health and Environmental Sciences, Xi' an

Jiaotong-Liverpool University, Suzhou 215123, China

e-mail: Linxi.Yuan@xjtlu.edu.cn

D. $\mathrm{Yu}$

Primary Care Centre Versus Arthritis, School of Medicine,

Keele University, Keele ST5 5BG, UK

B. Wang

Suzhou Centre for Disease Control and Prevention,

Suzhou 215004, China data of $\mathrm{Se}, \mathrm{Zn}, \mathrm{Fe}$ and $\mathrm{Cu}$ in surface soils (from the National Geochemical Survey), were mapped according to geographical location at the county level across conterminous USA. Characteristics of population, socio-demographics and residential environment by county were also collected. Seven cross-sectional sampling dates, with a 4-week interval between adjacent dates, constructed an observational investigation over 24 weeks from October 8, 2020, to March 25, 2021. Multivariable fractional (logit) outcome regression analyses were used to assess the association with adjustment for potential confounding factors. In USA counties with the lowest concentration of $\mathrm{Zn}$, the case fatality rate of COVID-19 was the highest, after adjustment for other influencing factors. Associations of $\mathrm{Se}, \mathrm{Fe}$ and $\mathrm{Cu}$ with case fatality rate of COVID19 were either inconsistent over time or disappeared after adjustment for $\mathrm{Zn}$. Our large study provides epidemiological evidence suggesting an association of $\mathrm{Zn}$ with COVID-19 severity, suggesting $\mathrm{Zn}$ deficiency should be avoided.

Keywords Trace element - Geographical distribution - COVID-19 - Case fatality rate . Ecological study $\cdot$ Environmental epidemiology

\section{Introduction}

The case fatality rate of patients with COVID-19 was very high in the very initial period of outbreak, 
approximately $30 \%$ according to a report from Wuhan (Zhou et al. 2020a, b). After a fight against this highly contagious disease for a period of time, the rate has been significantly reduced to approximately 2\% (Dong et al., 2020), thanks to the more effective management of the disease. However, due to the large scale, the disease burden has still remained as one of the top public health concerns for almost all countries around the world. The mortality due to COVID-19 has been shown to be associated with socio-demographic and clinical factors including being male, older age, deprivation, ethnicity, obesity, diabetes, severe asthma and other chronic conditions (Williamson et al., 2020; Yehia et al., 2020; Lassale et al., 2020; Aggarwal et al., 2020; Holman et al., 2020; AlSalameh et al., 2020).

The optimal status of specific nutrients is considered crucial to keep the normal function of human immune components. Specifically, based on the scientific evidence collected so far, the European Food Safety Authority deems four trace elements (selenium $(\mathrm{Se})$, zinc $(\mathrm{Zn})$, iron $(\mathrm{Fe})$ and copper $(\mathrm{Cu}))$ to be essential for the normal activity of the immune system (Scientific Opinion \& EFSA, 2009a, b, c, d, 2011).

$\mathrm{Se}$ is an important element for the normal function of human body with anti-inflammatory, antioxidant and immune effects (Yuan et al., 2022). Se deficiency in the host is related to RNA-virus replication and virulent mutations, which may lead to more severe symptoms of the infection (Liu et al., 2021). Zn, under physiological conditions, is essential for immunoregulatory functions including cellular growth and the maturation of immune cells, particularly in the development of activation of $\mathrm{T}$ cells (Wintergerst et al., 2006). The antiviral property of $\mathrm{Zn}$ has been studied extensively in various viral infections, including hepatitis $\mathrm{C}$ virus, Human Immunodeficiency Virus (HIV), and coronavirus (Barocas et al., 2019). Fe metabolism and anemia are proposed to be a possible factor playing an important role in multiple organ dysfunction syndromes in COVID-19 patients (Taneri et al., 2020). $\mathrm{Cu}$ is involved in the functions of critical immune cells including $\mathrm{T}$ cells, B cells, neutrophils killer cells and macrophages. People with $\mathrm{Cu}$ deficiency show an excess susceptibility to infections because of the decreased number and function of these immune cells above (Raha et al., 2020).
There have been a few research articles providing preliminary clinical evidences on associations between the physiological status of these trace elements and the outcome of COVID-19 (Zhang et al., 2020; Moghaddam et al., 2020; Im et al., 2020; Jothimani et al., 2020; Taneri et al., 2020), and several review papers proposing their therapeutic perspectives for COVID-19 treatment (Raha et al., 2020; Alexander et al., 2020; Shakoor et al., 2021; Calder, 2020; Calder et al., 2020). However, no study has investigated the geographical distributions of these elements and epidemiological features of COVID-19 on a large scale during the evolving epidemic. The concentrations of these elements in plants, animals and humans are fundamentally influenced by their geographical distributions (e.g., in soil and water). Geographical distributions of trace elements in the environment have been evident to influence the health of local population (Dinh et al., 2018). In China, notably, the incidence of Keshan disease (KD) was closely associated with soil Se concentration in the KD endemic areas (Zhang et al., 2019). Furthermore, the findings of many community trials showed that Se supplementation effectively prevented the occurrence of acute and sub-acute KD (Zhou et al., 2018). In USA, environmental cadmium (Cd) was found to be associated with mortality from influenza and pneumonia in the adult population (Park et al., 2020).

Hence, we hypothesized that variation in concentrations of immune function-related trace elements in the local environment may be related to the severity of COVID-19 in that region. In specific, we aimed to assess whether there are associations between the geographical distributions of $\mathrm{Se}, \mathrm{Zn}, \mathrm{Fe}$ and $\mathrm{Cu}$ in surface soils, and the case fatality rate of COVID-19, using the national data of USA reported at the county level.

\section{Materials and methods}

This is an ecological study ("Modern Epidemiology" 2020), with data from different USA geographical areas (on the national scale, and at the county level) correlating two sets of variables: epidemiological data (case fatality rate) of COVID-19, and geochemical concentration data of $\mathrm{Se}, \mathrm{Zn}, \mathrm{Fe}$ and $\mathrm{Cu}$. Characteristics of population, socio-demographics and 
residential environment in USA by county were also included for potential confounding adjustment.

\section{Data collection}

Geochemical concentrations of $\mathrm{Se}, \mathrm{Zn}, \mathrm{Fe}$ and $\mathrm{Cu}$ in surface soils (and stream sediments, from a depth of about $20 \mathrm{~cm}$ ) at the county level of USA were obtained through the National Geochemical Survey, analyzed during the period between 1997 and 2009. This dataset contains chemical analyses for more than 70,000 samples covering the majority of counties (3086/3140, 98.3\%) of the USA (Smith et al., 2013). The National Geochemical Survey, was conducted by the United States Geological Survey in collaboration with other federal and state government agencies, industry and academia. The survey aimed to produce a body of geochemical data using a consistent set of methods in order to provide the possible maximum level of internal consistency. The goal of the National Geochemical Survey was to analyze at least one sample in every $289 \mathrm{~km}^{2}$ area by a single set of analytical methods across the entire nation (Smith et al., 2013). Se concentration was determined by hydride-generation atomic absorption spectrometry (HG-AAS). The concentrations of $\mathrm{Zn}, \mathrm{Fe}$ and $\mathrm{Cu}$ were measured using inductively coupled plasma-atomic emission spectrometry (ICP-AES) (Smith et al., 2013). The concentrations of $\mathrm{Se}, \mathrm{Zn}, \mathrm{Fe}$ and $\mathrm{Cu}$, in this study, were reported as $\mathrm{mg} / \mathrm{kg}$ (i.e., $\mathrm{mg}$ of substance per $\mathrm{kg}$ of solid sample).

Geochemical data in the conterminous states were collected, so Alaska and Hawaii were not included. Data on the following 25 counties were also not available: St. Mary (in Louisiana), Nantucket (in Massachusetts), Keweenaw (in Michigan), Hudson (in New Jersey), Major and Woodward (in Oklahoma), Camp, Delta, Franklin, Gregg, Hansford, Hopkins, Kinney, Lipscomb, Loving, Maverick, Morris, Ochiltree, Rains, Smith, Titus, Upshur and Wood (in Texas), and Lexington and Manassas Park City (in Virginia).

Epidemiological data on the case fatality rate of COVID-19 (i.e., mortality rate per cases of COVID19) in each USA county were accessed from the COVID-19 interactive map from the University of John Hopkinson, which is a web-based dashboard to track COVID-19 in real-time on a daily basis (Dong et al., 2020). Numbers of cases and deaths in the interactive map included those confirmed and probable patients based on the reported information (Dong et al., 2020). To exclude potential bias, the analysis used the data of December 31, 2020. Thus, the analysis includes all the information up to the end of 2020 and excludes potential effects from the COVID-19 vaccination (that started from late December 2020). Six additional data points (October 8, 2020, November 5, 2020, December 3, 2020, January 28, 2021, February 25, 2021, March 25, 2021) were also used to perform validation analysis in order to question whether the findings were robust over time. A 4-week interval between adjacent data points was set among the seven study dates, constructing an observational investigation based on a total period of 24 weeks.

COVID-19 data (of December 31, 2020) was linked with geochemical data by county, in which 3057 counties were successfully mapped (3057/3086, 99.1\%). Unmapped counties included Garfield, Beaver, Kane, Uintah, Millard, Grand, Cache, Iron, Juab, Rich, Piute, Weber, Morgan, Daggett, Sanpete, Carbon, Washington, Duchesne, Box Elder, Sevier, Emery and Wayne (in Utah), Clifton Forge, Dade, Bedford City and South Boston (in Virginia), Yellowstone National Park (in Montana), Dukes (in Massachusetts), and Shannon (in South Dakota). Regional COVID-19 reported in these areas were summarized in a different way other than the level of county (e.g., Southwest region of Utah).

Information on population (including size, gender, age, ethnicity, and death rate), socio-demographics (including educational level, household income, unemployment rate, and poverty rate) and residential environment (including the Rural-Urban Continuum Code), by county, was collected from the USA national official sources. The information was all complete on the studied counties. Population size, gender, age and ethnic distribution, and death rate were collected from the US Bureau of the Census (data of 2019). Education information (among adults) was gathered from the US Bureau of the Census (the 2014-18 American Community Survey 5-year average county-level estimates). Household income data was collected from the US Bureau of the Census (Small area income and poverty estimates (SAIPE) Program, 2019 data). Unemployment rate was collected from the US Bureau of Labor Statistics (Local Area Unemployment Statistics (LAUS), 2019 data). Poverty information was collected from the US Bureau of the Census (SAIPE, 2018 data). 
Rural-Urban Continuum Code (created by Economic Research Service, US Department of Agriculture), used in the current analysis, was the latest version, published in 2013 ("USDA ERS-Rural-Urban Continuum Codes" 2021).

\section{Statistical analysis}

At the county level, descriptive statistics on the regional concentrations of $\mathrm{Se}, \mathrm{Zn}, \mathrm{Fe}$ and $\mathrm{Cu}$, and regional epidemiological data (number of cases, number of deaths, case fatality rate) of COVID-19 were presented at first. Spearman's correlation test was initially carried out to assess the correction between regional concentrations of $\mathrm{Se}, \mathrm{Zn}, \mathrm{Fe}$ and $\mathrm{Cu}$, and the regional COVID-19 case fatality rate. Spearman's correlation test was also used for demonstrating the correlations between the four studied trace elements.

Crude odds ratios (ORs) were calculated (with 95\% confidence intervals ( $95 \% \mathrm{CIs})$ ) to show the unadjusted association between each potential risk factor and the case fatality rate of COVID-19, using univariable fractional (logit) outcome regression models. Multivariable fractional (logit) outcome regression modeling was then used within each domain (geochemical data of trace elements, population characteristics, socio-demographics, and residential environment) to assess the independent associations of the significant factors from the univariable analysis. Then, all significant variables in the withindomain analyses were included in a final model, with all variables entered simultaneously.

Spatial linear regression modeling was also carried out as a sensitivity analysis to assess the above association after consideration of the spatial dependency of dependent variables (i.e., geochemical concentrations) ("Stata Bookstore I Spatial Autoregressive Models Reference Manual, Release 16" 2020). The present study created the spatial-weighting matrix using inverse distances among US counties based on the dot location of each county. Information about the location of each county was collected using dot locations (latitude and longitude) based on geographic centroids. Distance between the two counties was calculated based on the dot locations.

A $p$ value $<0.0125(0.05 / 4$, the Bonferroni correction for multiple testing problem), two-tailed, was considered statistically significant in all analyses, as four main research hypotheses were tested in this study (i.e., associations of $\mathrm{Se}, \mathrm{Zn}, \mathrm{Fe}$ and $\mathrm{Cu}$ with case fatality rate of COVID-19). All the statistical analyses were carried out using the STATA (version 15, StataCorp LLC, College Station, TX, USA).

\section{Results}

Geochemical concentrations of $\mathrm{Se}, \mathrm{Zn}, \mathrm{Fe}$ and $\mathrm{Cu}$, at the 3,057 USA counties included in the current study, were extracted from the National Geochemical Survey. Summary statistics is shown in Table 1. Correlations of geochemical concentrations between these elements are displayed in Supplementary Table 1.

County level summary of the latest information on population characteristics, socio-demographics and residential environment index in USA is shown in Table 2.

In the studied USA counties, up to December 31, 2020, the total cumulative number of COVID-19 cases was $19,286,619$, and the total mortality from COVID-19 was 337,696 (i.e., the overall case fatality rate, $1.75 \%$ ). By county, the median case fatality rate was $1.55 \%$ (interquartile range (IQR) $1.02 \%, 2.30 \%$ ). Statistics based on other time points is shown in Supplementary Table 2 .

Geographical patterns of $\mathrm{Se}, \mathrm{Zn}, \mathrm{Fe}$ and $\mathrm{Cu}$ concentrations, and COVID-19 case fatality rate (based on the data of December 31, 2020) across conterminous USA at the county level are visualized in Fig. 1. Notably, in the south-east region where concentrations of $\mathrm{Se}, \mathrm{Zn}, \mathrm{Fe}$ and $\mathrm{Cu}$ are relatively low (in blue), the case fatality rate of COVID-19 is relatively high
Table 1 Geochemical concentrations of $\mathrm{Se}, \mathrm{Zn}$, $\mathrm{Fe}$ and $\mathrm{Cu}$ at the USA county level according to the national geochemical survey

\begin{tabular}{lclcc}
\hline Trace elements & \multicolumn{1}{l}{ Median } & Interquartile range & \multicolumn{1}{l}{ Mean } & Standard deviation \\
\hline $\mathrm{Se}, \mathrm{mg} / \mathrm{kg}$ & 0.275 & $0.186,0.411$ & 0.338 & 0.258 \\
$\mathrm{Zn}, \mathrm{mg} / \mathrm{kg}$ & 55.062 & $35.815,73.603$ & 59.689 & 48.337 \\
$\mathrm{Fe}, \mathrm{mg} / \mathrm{kg}$ & $21,994.6$ & $16,146.7,28,109.5$ & $23,498.1$ & $12,592.9$ \\
$\mathrm{Cu}, \mathrm{mg} / \mathrm{kg}$ & 12.264 & $7.894,17.497$ & 14.395 & 13.631 \\
\hline
\end{tabular}


Table 2 County level summary of population characteristics, socio-demographics and residential environment index

\begin{tabular}{|c|c|}
\hline Characteristics & Number $(\%)$, or median (IQR) \\
\hline \multicolumn{2}{|l|}{ Population information } \\
\hline Size & $26,234(11,195,69,432)$ \\
\hline Gender, male & $49.7 \%(49.0 \%, 50.6 \%)$ \\
\hline Ethnicity, white alone & $91.3 \%(79.9 \%, 95.4 \%)$ \\
\hline \multicolumn{2}{|l|}{ Age, years } \\
\hline $0-9$ & $11.7 \%(10.5 \%, 12.8 \%)$ \\
\hline $10-19$ & $12.6 \%(11.6 \%, 13.6 \%)$ \\
\hline $20-29$ & $11.7 \%(10.4 \%, 13.0 \%)$ \\
\hline $30-39$ & $11.6 \%(10.7 \%, 12.7 \%)$ \\
\hline $40-49$ & $11.5 \%(10.7 \%, 12.3 \%)$ \\
\hline $50-59$ & $13.4 \%(12.5 \%, 14.2 \%)$ \\
\hline $60-69$ & $13.2 \%(11.8 \%, 14.7 \%)$ \\
\hline $70-79$ & $8.5 \%(7.3 \%, 9.8 \%)$ \\
\hline 80 and over & $4.7 \%(3.8 \%, 5.6 \%)$ \\
\hline Death rate & $10.5 \%(8.9 \%, 12.3 \%)$ \\
\hline \multicolumn{2}{|l|}{ Socio-demographics } \\
\hline \multicolumn{2}{|l|}{ Educational level, adults (\%) } \\
\hline Less than a high school diploma & $12.1 \%(8.8 \%, 17.2 \%)$ \\
\hline A high school diploma only & $34.6 \%(29.9 \%, 39.3 \%)$ \\
\hline Completing some college or associate's degree & $30.6 \%(27.2 \%, 34.2 \%)$ \\
\hline A bachelor's degree or higher & $19.2 \%(15.0 \%, 25.5 \%)$ \\
\hline Median household income (annual, US dollar) & $50,464(43,584,58,515)$ \\
\hline Unemployment rate $(\%)$ & $3.7 \%(3.0 \%, 4.6 \%)$ \\
\hline Poverty rate $(\%)$ & $14.2 \%(10.9 \%, 18.3 \%)$ \\
\hline \multicolumn{2}{|l|}{ Rural-Urban Continuum Code } \\
\hline 1 (Metro areas, 1 million population or more) & $428(14.0)$ \\
\hline 2 (Metro areas, 250 thousand to 1 million population) & $371(12.1)$ \\
\hline 3 (Metro areas, population fewer than 250 thousand) & $348(11.4)$ \\
\hline 4 (Urban population of 20 thousand or more, adjacent to a metro area) & $212(6.9)$ \\
\hline 5 (Urban population of 20 thousand or more, not adjacent to a metro area) & $88(2.9)$ \\
\hline 6 (Urban population of 2,500 to 19,999 , adjacent to a metro area) & $585(19.1)$ \\
\hline 7 (Urban population of 2,500 to 19,999 , not adjacent to a metro area) & $409(13.4)$ \\
\hline 8 (Completely rural or less than 2,500 urban population, adjacent to a metro area) & $216(7.1)$ \\
\hline 9 (Completely rural or less than 2,500 urban population, not adjacent to a metro area) & $400(13.1)$ \\
\hline
\end{tabular}

$I Q R$, Interquartile range

(in yellow or orange); whereas in the west coast area where $\mathrm{Zn}, \mathrm{Fe}$ and $\mathrm{Cu}$ are high (in yellow or orange), the case fatality rate is low (in blue), suggesting an overall pattern of inverse association, especially for $\mathrm{Zn}, \mathrm{Fe}$ and $\mathrm{Cu}$.

Preliminary correlation analysis showed that regional geochemical concentrations were inversely associated with regional case fatality rate of COVID19 (Se $r=-0.053, p=0.0037$; Zn $r=-0.162$, $p<0.0001 ; \quad$ Fe $\quad r=-0.159, \quad p<0.0001 ; \quad \mathrm{Cu}$ $r=-0.164, p<0.0001$, data of December 31, 2020) at the county level. By quartiles of each geochemical concentration, case fatality rates of COVID-19 (based on December 31, 2020 and other six time points) at the county level are shown in Table 3. It was observed that the case fatality rate mainly differed between the lowest quartile (1st quartile) and the other three (2-4th) quartiles for $\mathrm{Zn}, \mathrm{Fe}$ and $\mathrm{Cu}$ concentrations 


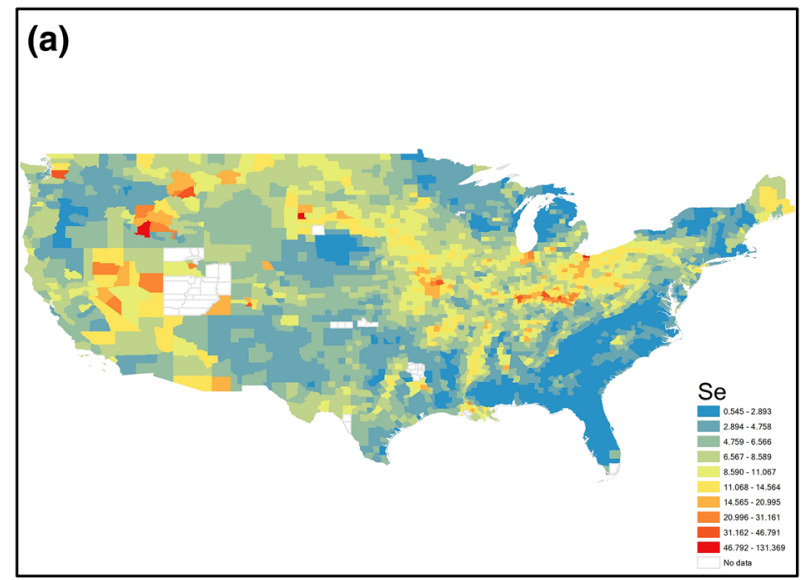

(b)

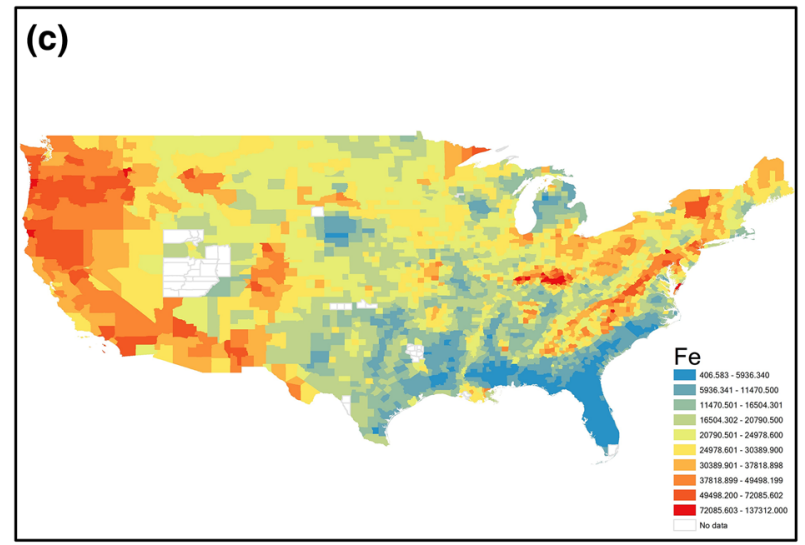

(d)

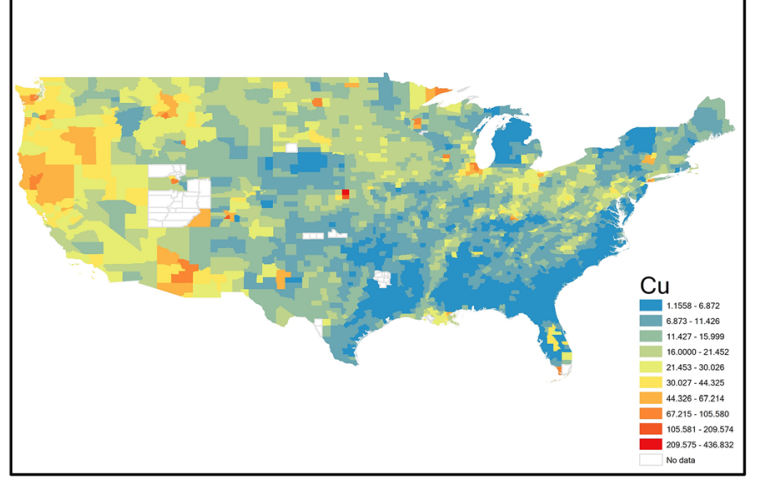

(e)

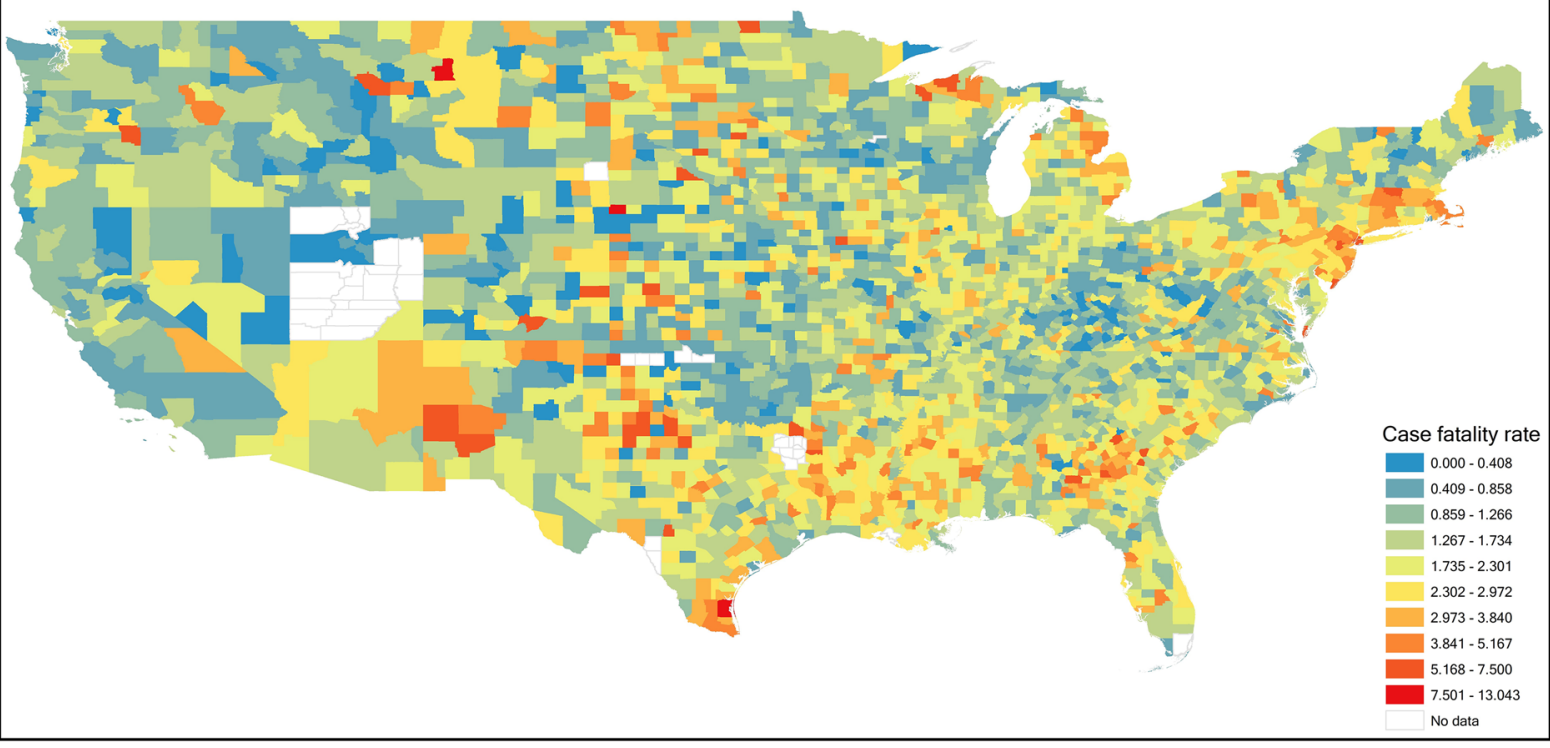


4Fig. 1 Geographical patterns of $\mathrm{Se}, \mathrm{Zn}, \mathrm{Fe}$ and $\mathrm{Cu}$ concentrations and COVID-19 case fatality rate across conterminous USA at the county level. COVID-19 case fatality rate, based on the data of December 31, 2020. (Color print)

(Table 3). The inverse association between $\mathrm{Se}$ and case fatality rate however was not found consistently over time (Table 3 ). Thus, only regional $\mathrm{Zn}, \mathrm{Fe}$ and $\mathrm{Cu}$ concentrations then were divided into two groups (1st quartile vs. 2-4th quartiles) for later statistical analysis (Fig. 2).

In fractional regression models, all the studied variables, except for population size, were found to be associated with the case fatality rate of COVID19 in the univariable analyses (Model 1, Table 4). After adjustment within each domain, $\mathrm{Zn}$ concentration (from trace element domain), white alone, age $\geq 70$ years and death rate (from population information domain), poverty rate (from socio-demographic domain), and the Rural-Urban Continuum Code (from residential environment domain) were still associated (Model 2, Table 4).

In the final model, the lowest quartile of $\mathrm{Zn}$ concentration (OR (95\% CI), 1.13 (1.07, 1.19), compared to the rest three quartiles as a whole) remained statistically significant in association with the increased rate of case fatality of COVID-19 after confounding adjustment (Model 3, Table 4). The same statistical modeling using COVID-19 data at different time points revealed consistent results with only a slight difference in ORs (1.09-1.21, Fig. 3). Spatial regression analyses demonstrated the same findings (data not shown).

\section{Discussion}

This study, consisting of all cumulative case and mortality information of COVID-19, and geochemical concentrations of immune function-related trace elements (including $\mathrm{Se}, \mathrm{Zn}, \mathrm{Fe}$ and $\mathrm{Cu}$ ) across conterminous USA, has shown there is an inverse association between regional $\mathrm{Zn}$ concentration and COVID-19 case fatality rate based on a county level analysis. An increased risk of death from COVID-19 was observed in counties with the lowest concentration of $\mathrm{Zn}$ in surface soils, and this observation was consistent over time during our assessment period (first sampling time point October 8, 2020, and last point March 25,
2021). The concentrations of trace elements in human body are fundamentally influenced by geochemical distribution via the food chain, and this has been evident to impact the health of the local population (Johnson et al., 2010; Pepper, 2013; Steffan et al., 2018). Particularly, it has been shown that low concentration of $\mathrm{Zn}$ in soil is one of the major factors associated with $\mathrm{Zn}$ deficiency in crops and humans (Alloway, 2009; Gashu et al., 2021).

In the literature, in an Indian study among COVID-19 patients at the time of hospitalization, patients with $\mathrm{Zn}$ deficiency were found to have higher rates of complications, acute respiratory distress syndrome, corticosteroid therapy, prolonged hospital stay and increased mortality, compared to those without Zn deficiency (Jothimani et al., 2020). A study carried out in Japan also demonstrated that prolonged $\mathrm{Zn}$ deficiency was associated with critical illness of COVID-19 in hospitalized patients (Yasui et al., 2020). In a Brazilian study on COVID-19 patients in the intensive care unit, the prevalence of low serum $\mathrm{Zn}$ level ( $\mathrm{Zn}$ deficiency) was as high as $80 \%$, and there was a very strong association between $\mathrm{Zn}$ deficiency and severe COVID-19 with an adjusted OR of 15 (Gonçalves et al., 2021). A Spanish team showed (1) in a cohort of hospitalized COVID-19 patients that lower serum levels of $\mathrm{Zn}$ at admission were associated with worse clinical presentation, longer time to reach stability and higher mortality; and (2) in vitro that low $\mathrm{Zn}$ levels favored viral expansion in SARS-CoV-2 infected cells (Vogel-González et al., 2021). Zn, selenoprotein $P$ and age, as a composite biomarker, proved to be a good predictor of survival odds in COVID-19 (Heller et al., 2021). However, $\mathrm{Zn}$ therapy provided during treatment after hospital admission for COVID-19 was not associated with disease mortality, from a retrospective observational study (Yao et al., 2021). A randomized trial of ambulatory patients diagnosed with COVID-19 showed that treatment of high-dose $\mathrm{Zn}$ for 10 days was not beneficial to symptom reduction including fever, cough, shortness of breath and fatigue, compared to the usual care (Thomas et al., 2021).

A robust association of geochemical Se concentration with case fatality of COVID-19 was not consistently seen over the assessment period, though there seemed to be an association according to the early period (up to 3rd December). For $\mathrm{Fe}$ and $\mathrm{Cu}$, it was suggested that these apparent associations may be due 
Table 3 Case fatality rate of COVID-19 stratified by quartiles of geochemical concentrations ( $\mathrm{Se}, \mathrm{Zn}, \mathrm{Fe}$ and $\mathrm{Cu}$ ) at the USA county level, assessed at multiple time points over 24 weeks

\begin{tabular}{|c|c|c|c|c|c|c|c|}
\hline \multirow{2}{*}{$\begin{array}{l}\text { Quartiles } \\
\text { based on con- } \\
\text { centrations of } \\
\text { trace elements }\end{array}$} & \multicolumn{7}{|c|}{ Case fatality rate of COVID-19 at the county level (\%) } \\
\hline & $\begin{array}{l}\text { October } 8, \\
2020\end{array}$ & $\begin{array}{l}\text { November 5, } \\
2020\end{array}$ & $\begin{array}{l}\text { December 3, } \\
2020\end{array}$ & $\begin{array}{l}\text { December 31, } \\
2020\end{array}$ & $\begin{array}{l}\text { January 28, } \\
2021\end{array}$ & $\begin{array}{l}\text { February 25, } \\
2021\end{array}$ & March 25, 2021 \\
\hline \multicolumn{8}{|l|}{$\begin{array}{l}\text { Se concentra- } \\
\text { tion }\end{array}$} \\
\hline $\begin{array}{l}\text { 1st quartile } \\
\text { (lowest) }\end{array}$ & $\begin{array}{l}1.91(1.03, \\
3.14)\end{array}$ & $\begin{array}{l}1.82(1.09, \\
2.97)\end{array}$ & $\begin{array}{l}1.75(1.06, \\
2.72)\end{array}$ & $\begin{array}{l}1.67(1.10, \\
2.48)\end{array}$ & $\begin{array}{l}1.77(1.16 \\
2.49)\end{array}$ & $\begin{array}{l}1.90(1.32 \\
2.60)\end{array}$ & $\begin{array}{l}1.97(1.39, \\
2.70)\end{array}$ \\
\hline 2nd quartile & $\begin{array}{l}1.71(0.82, \\
3.02)\end{array}$ & $\begin{array}{c}1.68(0.93, \\
2.93)\end{array}$ & $\begin{array}{c}1.57(0.95, \\
2.39)\end{array}$ & $\begin{array}{l}1.57(0.98, \\
2.31)\end{array}$ & $\begin{array}{l}1.68(1.12 \\
2.36)\end{array}$ & $\begin{array}{c}1.80(1.25 \\
2.45)\end{array}$ & $\begin{array}{l}1.85(1.30 \\
2.48)\end{array}$ \\
\hline 3rd quartile & $\begin{array}{l}1.57(0.72, \\
2.73)\end{array}$ & $\begin{array}{l}1.52(0.84, \\
2.51)\end{array}$ & $\begin{array}{c}1.37(0.84, \\
2.18)\end{array}$ & $\begin{array}{c}1.46(0.98 \\
2.13)\end{array}$ & $\begin{array}{l}1.56(1.10 \\
2.21)\end{array}$ & $\begin{array}{c}1.72(1.24, \\
2.36)\end{array}$ & $\begin{array}{c}1.76(1.31, \\
2.36)\end{array}$ \\
\hline 4th quartile & $\begin{array}{l}1.28(0.50 \\
2.77)\end{array}$ & $\begin{array}{l}1.31(0.65 \\
2.49)\end{array}$ & $\begin{array}{l}1.31(0.77, \\
2.18)\end{array}$ & $\begin{array}{l}1.51(1.03 \\
2.32)\end{array}$ & $\begin{array}{l}1.63(1.11 \\
2.37)\end{array}$ & $\begin{array}{l}1.77(1.22 \\
2.52)\end{array}$ & $\begin{array}{l}1.81(1.25, \\
2.51)\end{array}$ \\
\hline \multicolumn{8}{|l|}{$\begin{array}{l}\text { Zn concentra- } \\
\text { tion }\end{array}$} \\
\hline $\begin{array}{l}\text { 1st quartile } \\
\text { (lowest) }\end{array}$ & $\begin{array}{l}2.13(1.28 \\
3.35)\end{array}$ & $\begin{array}{l}2.14(1.25 \\
3.25)\end{array}$ & $\begin{array}{l}1.99(1.30 \\
2.96)\end{array}$ & $\begin{array}{l}1.90(1.29, \\
2.67)\end{array}$ & $\begin{array}{l}1.93(1.40, \\
2.65)\end{array}$ & $\begin{array}{l}2.04(1.48, \\
2.75)\end{array}$ & $\begin{array}{l}2.08(1.54, \\
2.83)\end{array}$ \\
\hline 2nd quartile & $\begin{array}{l}1.56(0.73, \\
2.64)\end{array}$ & $\begin{array}{c}1.49(0.84, \\
2.49)\end{array}$ & $\begin{array}{c}1.40(0.89, \\
2.27)\end{array}$ & $\begin{array}{c}1.48(1.01 \\
2.20)\end{array}$ & $\begin{array}{l}1.58(1.09 \\
2.24)\end{array}$ & $\begin{array}{c}1.70(1.21, \\
2.36)\end{array}$ & $\begin{array}{c}1.76(1.29 \\
2.38)\end{array}$ \\
\hline 3rd quartile & $\begin{array}{l}1.20(0.46, \\
2.45)\end{array}$ & $\begin{array}{l}1.26(0.61, \\
2.25)\end{array}$ & $\begin{array}{l}1.28(0.77, \\
2.00)\end{array}$ & $\begin{array}{c}1.43(0.96 \\
2.13)\end{array}$ & $\begin{array}{l}1.54(1.07 \\
2.25)\end{array}$ & $\begin{array}{l}1.71(1.15 \\
2.43)\end{array}$ & $\begin{array}{c}1.75(1.22 \\
2.45)\end{array}$ \\
\hline 4th quartile & $\begin{array}{c}1.66(0.66, \\
3.05)\end{array}$ & $\begin{array}{l}1.53(0.75 \\
2.65)\end{array}$ & $\begin{array}{l}1.38(0.82 \\
2.14)\end{array}$ & $\begin{array}{c}1.40(0.96 \\
2.11)\end{array}$ & $\begin{array}{l}1.52(1.07 \\
2.22)\end{array}$ & $\begin{array}{c}1.68(1.21, \\
2.34)\end{array}$ & $\begin{array}{c}1.73(1.25 \\
2.35)\end{array}$ \\
\hline \multicolumn{8}{|l|}{$\begin{array}{l}\text { Fe concentra- } \\
\text { tion }\end{array}$} \\
\hline $\begin{array}{l}\text { 1st quartile } \\
\text { (lowest) }\end{array}$ & $\begin{array}{l}2.09(1.20, \\
3.31)\end{array}$ & $\begin{array}{l}2.08(1.20 \\
3.25)\end{array}$ & $\begin{array}{l}1.97(1.25, \\
2.93)\end{array}$ & $\begin{array}{c}1.89(1.25 \\
2.64)\end{array}$ & $\begin{array}{l}1.95(1.36 \\
2.66)\end{array}$ & $\begin{array}{l}2.04(1.45, \\
2.76)\end{array}$ & $\begin{array}{l}2.07(1.53, \\
2.79)\end{array}$ \\
\hline 2nd quartile & $\begin{array}{l}1.35(0.56 \\
2.48)\end{array}$ & $\begin{array}{l}1.40(0.70, \\
2.30)\end{array}$ & $\begin{array}{l}1.37(0.86 \\
2.17)\end{array}$ & $\begin{array}{c}1.50(0.98 \\
2.25)\end{array}$ & $\begin{array}{l}1.62(1.12 \\
2.40)\end{array}$ & $\begin{array}{l}1.74(1.20 \\
2.47)\end{array}$ & $\begin{array}{c}1.79(1.25 \\
2.49)\end{array}$ \\
\hline 3rd quartile & $\begin{array}{l}1.27(0.50 \\
2.62)\end{array}$ & $\begin{array}{l}1.31(0.67, \\
2.37)\end{array}$ & $\begin{array}{l}1.26(0.77, \\
2.04)\end{array}$ & $\begin{array}{l}1.45(0.99 \\
2.17)\end{array}$ & $\begin{array}{l}1.57(1.08 \\
2.27)\end{array}$ & $\begin{array}{l}1.70(1.22 \\
2.42)\end{array}$ & $\begin{array}{l}1.72(1.26 \\
2.46)\end{array}$ \\
\hline 4th quartile & $\begin{array}{l}1.83(0.89, \\
3.13)\end{array}$ & $\begin{array}{l}1.63(0.93, \\
2.74)\end{array}$ & $\begin{array}{l}1.48(0.92, \\
2.22)\end{array}$ & $\begin{array}{l}1.41(0.96 \\
2.05)\end{array}$ & $\begin{array}{l}1.47(1.02 \\
2.11)\end{array}$ & $\begin{array}{l}1.65(1.15 \\
2.28)\end{array}$ & $\begin{array}{l}1.72(1.23 \\
2.29)\end{array}$ \\
\hline \multicolumn{8}{|l|}{$\begin{array}{l}\mathrm{Cu} \text { concentra- } \\
\text { tion }\end{array}$} \\
\hline $\begin{array}{l}\text { 1st quartile } \\
\text { (lowest) }\end{array}$ & $\begin{array}{l}2.09(1.22, \\
3.35)\end{array}$ & $\begin{array}{l}2.08(1.21, \\
3.26)\end{array}$ & $\begin{array}{l}1.91(1.22, \\
2.86)\end{array}$ & $\begin{array}{l}1.84(1.17 \\
2.57)\end{array}$ & $\begin{array}{l}1.86(1.30 \\
2.53)\end{array}$ & $\begin{array}{l}1.99(1.41, \\
2.64)\end{array}$ & $\begin{array}{l}2.03(1.51, \\
2.74)\end{array}$ \\
\hline 2nd quartile & $\begin{array}{c}1.66(0.79 \\
2.78)\end{array}$ & $\begin{array}{l}1.57(0.92, \\
2.70)\end{array}$ & $\begin{array}{l}1.52(0.96 \\
2.42)\end{array}$ & $\begin{array}{l}1.58(1.06 \\
2.36)\end{array}$ & $\begin{array}{l}1.70(1.17 \\
2.47)\end{array}$ & $\begin{array}{l}1.83(1.31 \\
2.59)\end{array}$ & $\begin{array}{l}1.87(1.34, \\
2.57)\end{array}$ \\
\hline 3rd quartile & $\begin{array}{c}1.34(0.52 \\
2.70)\end{array}$ & $\begin{array}{l}1.33(0.62 \\
2.43)\end{array}$ & $\begin{array}{l}1.31(0.76, \\
2.13)\end{array}$ & $\begin{array}{c}1.43(0.96 \\
2.14)\end{array}$ & $\begin{array}{l}1.57(1.08 \\
2.28)\end{array}$ & $\begin{array}{l}1.73(1.20 \\
2.41)\end{array}$ & $\begin{array}{l}1.75(1.25 \\
2.45)\end{array}$ \\
\hline 4th quartile & $\begin{array}{c}1.48(0.57 \\
2.70)\end{array}$ & $\begin{array}{l}1.43(0.70 \\
2.38)\end{array}$ & $\begin{array}{l}1.31(0.79 \\
2.00)\end{array}$ & $\begin{array}{l}1.39(0.96, \\
2.03)\end{array}$ & $\begin{array}{l}1.46(1.00 \\
2.08)\end{array}$ & $\begin{array}{l}1.60(1.14, \\
2.20)\end{array}$ & $\begin{array}{c}1.67(1.19, \\
2.26)\end{array}$ \\
\hline
\end{tabular}

Reported values are median (interquartile range); COVID-19, coronavirus disease 2019. Sample (USA county) number, total 3057, in each quartile 764 or 765

to their co-existence with $\mathrm{Zn}$ based on the multivariable regression analyses. In the literature, using the epidemiological pattern during the initial outbreak in China, preliminary results showed there was an inverse association between regional Se status (data on hair Se concentration) and mortality rate among 

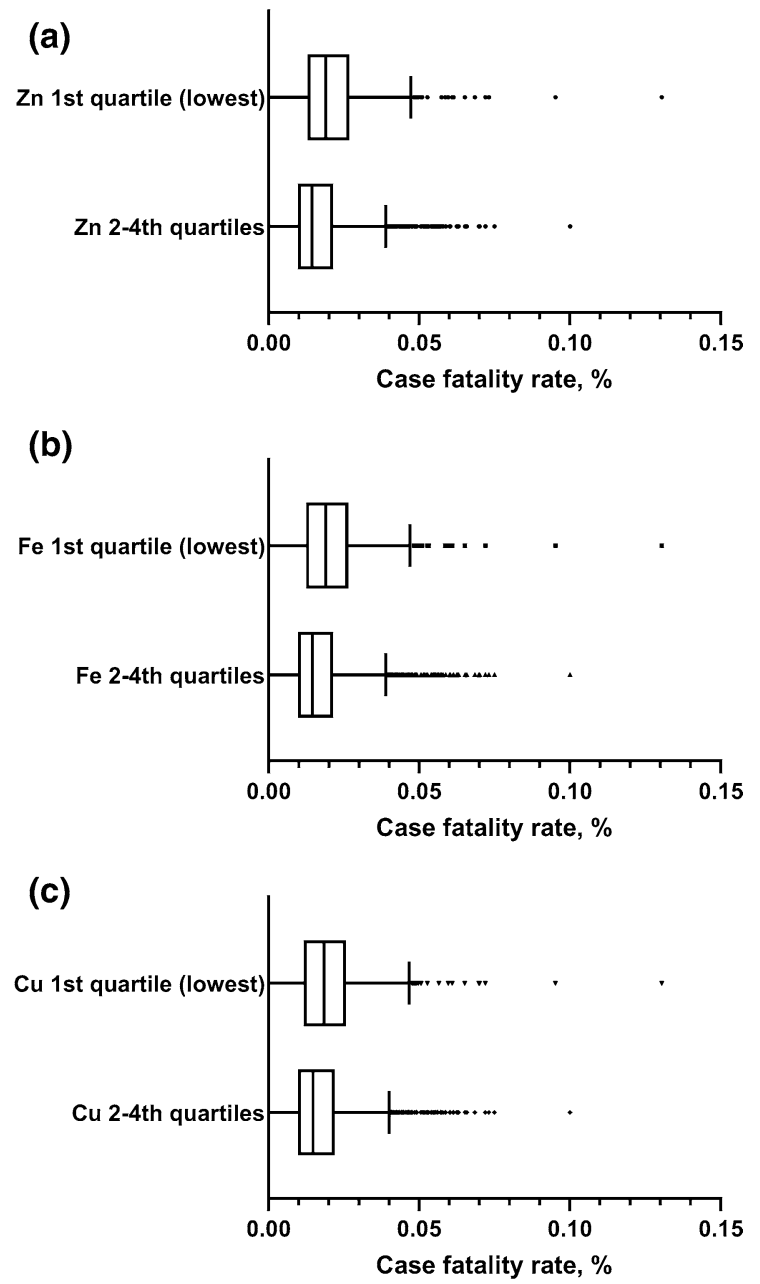

Fig. 2 Box plot of county level case fatality rate of COVID19 in the 1 st quartile (lowest) of $\mathrm{Zn}, \mathrm{Fe}$ or $\mathrm{Cu}$ concentration, compared to 2-4th quartiles as a whole. Mann-Whitney $U$ test for the difference in case fatality rate between the two comparison groups (by $\mathrm{Zn}$, median rate $1.90 \mathrm{vs} .1 .45, p<0.0001$; by $\mathrm{Fe}$, median rate 1.89 vs. $1.45, p<0.0001$; by $\mathrm{Cu}$, median rate 1.84 vs. $1.48, p<0.0001)$. COVID-19 case fatality rate, based on the data of December 31, 2020

COVID-19 patients (Zhang et al., 2020). A study from Germany, using serum samples to measure the total Se (by X-ray fluorescence) and selenoprotein $P$ (by ELISA), demonstrated that among COVID19 patients, the Se status was significantly higher in those who survived from the disease compared to those who did not, a more direct evidence suggesting Se deficiency may be a risk for COVID-19 mortality (Moghaddam et al., 2020). Clinical data on patients with COVID-19 and their matched control subjects in South Korea also arrived at a similar conclusion that a deficiency of Se may decrease the immune defenses against COVID-19 and lead to more severe disease (Im et al., 2020). With regard to Fe, it was shown that, compared to moderate patients, patients with severe COVID-19 had lower hemoglobin and red blood cell counts, and higher level of ferritin (Taneri et al., 2020). A combination test of hepcidin and serum ferritin was found to have good prediction value for COVID-19 severity (Zhou et al., 2020a, b). Hepcidin levels alone also showed as a predictor for the severity and mortality of COVID-19 in a group of hospitalized patients (Nai et al., 2021). Hyperferritinemia in COVID-19 was demonstrated to be associated with sustained inflammatory process, lung pathologies in computed tomography scans, poor patients' preference, and mortality (Perricone et al., 2020; Sonnweber et al., 2020). We are fully aware of that under common circumstances the environmental factors, contributing to health outcomes, are usually weak or undetectable, and the non-significant results in our ecological investigation certainly would not challenge the existing clinical evidence.

The availability and quality of geochemical and COVID-19 data across USA offer a novel opportunity (linked database research) to investigate the relationship between the environmental concentrations of nutrient trace elements and the COVID-19 case fatality rate. It allows the study to use a fairly large sample size in terms of the number of COVID-19 patients, and the geographical range and diversity. On February 22, 2021, fatalities from COVID-19 surpassed half a million across USA. This prolonged epidemic unfortunately has affected people at on the whole USA national scale for many months. However, from the research perspective, it provides a generalized (i.e., less biased) setting where the epidemic situations between counties have become more similar and the treatments become more standard. In this study, the main results were based on the COVID-19 data of December 31, 2020, 10 months after the first death from COVID-19 reported in USA. This study also benefits from USA as a well-developed country with relatively good health care resources across the whole nation, compared to the developing world where regional (e.g., urban vs. rural) difference may contribute more significantly to the quality of health care and therefore the outcome of diseases. Nevertheless, in the current study, residential environment (measured 
Table 4 Multivariable analyses for the relationship between trace elements ( $\mathrm{Zn}, \mathrm{Fe}$ and $\mathrm{Cu}$ ) and case fatality rate of COVID-19 with adjustment for other potential confounding factors

\begin{tabular}{|c|c|c|c|}
\hline Variable & Model 1, unadjusted & $\begin{array}{l}\text { Model 2, domain adjustment } \\
\text { OR }(95 \% \text { CI })\end{array}$ & Model 3, final model \\
\hline \multicolumn{4}{|l|}{ Trace elements } \\
\hline \multicolumn{4}{|l|}{ Zn concentration } \\
\hline 2-4th quartiles & 1.00 referent & 1.00 referent & 1.00 referent \\
\hline 1st quartile (lowest) & $1.25(1.19,1.32) \dagger$ & $1.19(1.09,1.30) \dagger$ & $1.13(1.07,1.19) \dagger$ \\
\hline \multicolumn{4}{|l|}{ Fe concentration } \\
\hline 2-4th quartiles & 1.00 referent & 1.00 referent & l \\
\hline 1st quartile (lowest) & $1.22(1.16,1.28) \dagger$ & $1.06(0.99,1.14)$ & / \\
\hline \multicolumn{4}{|l|}{$\mathrm{Cu}$ concentration } \\
\hline 2-4th quartiles & 1.00 referent & 1.00 referent & l \\
\hline 1st quartile (lowest) & $1.18(1.12,1.24) \dagger$ & $1.01(0.93,1.08)$ & / \\
\hline \multicolumn{4}{|l|}{ Population information } \\
\hline Population size (per 100,000 ) & $1.00(0.99,1.01)$ & l & l \\
\hline Male (\%) & $0.98(0.96,0.99) \dagger$ & $1.00(0.98,1.01)$ & l \\
\hline White alone (\%) & $0.99(0.99,0.99) \dagger$ & $0.99(0.99,0.99) \dagger$ & $0.99(0.99,1.00) \dagger$ \\
\hline Age $\geq 70$ years $(\%)$ & $1.03(1.02,1.04) \dagger$ & $1.03(1.02,1.04) \dagger$ & $1.03(1.02,1.04) \dagger$ \\
\hline Death rate $(\%)$ & $1.06(1.05,1.08) \dagger$ & $1.04(1.02,1.05) \dagger$ & $1.04(1.02,1.05) \dagger$ \\
\hline \multicolumn{4}{|l|}{ Socio-demographics } \\
\hline Bachelor's degree or higher $(\%)$ & $0.99(0.99,0.99) \dagger$ & $1.00(0.99,1.00)$ & l \\
\hline Median household income (per $1,000 \$$ ) & $0.99(0.99,0.99) \dagger$ & $1.00(0.99,1.00)$ & / \\
\hline Unemployment rate $(\%)$ & $1.06(1.04,1.08) \dagger$ & $1.01(1.00,1.03)$ & / \\
\hline Poverty rate $(\%)$ & $1.02(1.02,1.02) \dagger$ & $1.01(1.01,1.02) \dagger$ & $1.01(1.00,1.01)$ \\
\hline \multicolumn{4}{|l|}{ Residential environment } \\
\hline \multicolumn{4}{|l|}{ Rural-Urban Continuum Code } \\
\hline 1 & 1.00 referent & 1.00 referent & 1.00 referent \\
\hline 2 & $1.00(0.92,1.08)$ & $1.00(0.92,1.08)$ & $0.91(0.85,0.99)$ \\
\hline 3 & $1.03(0.94,1.12)$ & $1.03(0.94,1.12)$ & $0.93(0.85,1.01)$ \\
\hline 4 & $1.01(0.92,1.11)$ & $1.01(0.92,1.11)$ & $0.90(0.82,0.99)$ \\
\hline 5 & $0.92(0.80,1.06)$ & $0.92(0.80,1.06)$ & $0.85(0.75,0.96) \dagger$ \\
\hline 6 & $1.17(1.09,1.26) \dagger$ & $1.17(1.09,1.26) \dagger$ & $0.96(0.89,1.04)$ \\
\hline 7 & $1.09(1.01,1.19)$ & $1.09(1.01,1.19)$ & $0.91(0.84,1.00)$ \\
\hline 8 & $1.17(1.06,1.30) \dagger$ & $1.17(1.06,1.30) \dagger$ & $0.91(0.82,1.02)$ \\
\hline 9 & $1.17(1.05,1.30) \dagger$ & $1.17(1.05,1.30) \dagger$ & $0.96(0.86,1.08)$ \\
\hline
\end{tabular}

${ }^{\dagger} p$ value $<0.0125$; Case fatality rate of COVID-19 (outcome variable), based on the data of December 31, 2020

by Rural-Urban Continuum Code) was considered for adjustment as a confounding factor in the final statistical modeling, as well as other county level variables including population characteristics and socialdemographics. Concentrations of trace elements at the county level were the only data from the National Geochemical Survey. Additional information, such as other parameters of samples that determine the bioavailability of the analyzed elements, was not available. Many other variables (such as food source and details of health care service), which differ among counties, were also not available, which became one obvious limitation of this study.

We did not study the incidence rate (i.e., the percentage of cases among the total population) of COVID-19. As a disease of high contagion, the incidence of COVID-19 should be more related to population characteristics (e.g., age, comorbidity) and density, living environment (e.g., urban vs. rural area) and condition, ways of transportation, 


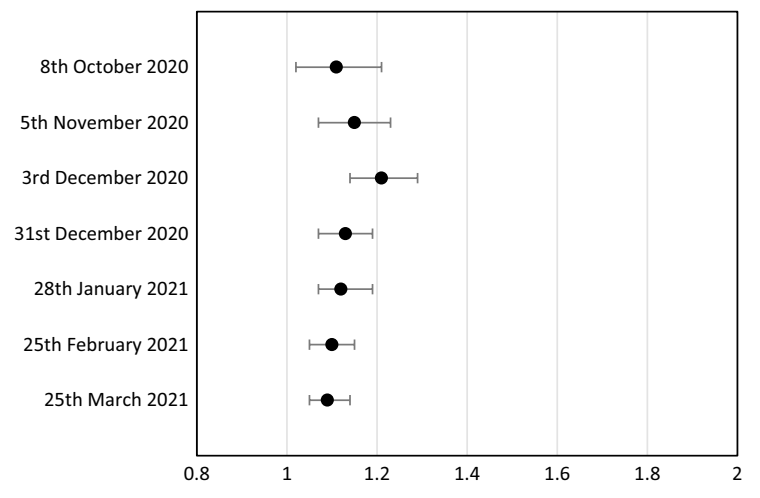

Fig. 3 Increased case fatality rate of COVID-19 in counties with the lowest quartile of $\mathrm{Zn}$ concentration over time, measured by adjusted odds ratios

protection behaviors (e.g., wearing mask, washing hands regularly), local regulations on social activities, and weather and air conditions. It is also more likely to be associated with individual policies and reporting systems of regional areas. We considered that COVID-19 vaccination, which started from the late December 2020 in USA, may serve as a factor influencing the association of interest. However, based on the validation analysis that used the data up to March 25, 2021, the observed association still remained consistent.

In conclusion, this study is the first to establish the geographical relationship between distributions of trace elements and features of COVID-19 at a very large scale. The results show that, in USA counties associated with relatively low geochemical concentration of $\mathrm{Zn}$ in surface soils, the case fatality rate of COVID-19 in those counties is relatively high, after consideration of other influencing factors. Our findings serve as a strong epidemiological support to the current literature which has focused mainly on preliminary clinical evidence suggesting a possible association of $\mathrm{Zn}$, important for maintaining normal immune function, with COVID19 severity, suggesting $\mathrm{Zn}$ deficiency should be avoided. To provide more direct evidence, future research to investigate the relationship between these trace elements in food and drinking water, and COVID-19 characteristics is needed.

Acknowledgements The authors thank the other colleagues at the Department of Health and Environmental Sciences,
Xi' an Jiaotong-Liverpool University for their academic and administrative support.

Authors' contributions YC, LY and ZFM conceived the study. YC analyzed the data and drafted the initial manuscript. All authors contributed to the study design and interpretation of the data, and all authors approved the final version of the manuscript submitted for publication.

Funding No funding was received for conducting this study.

Data availability The data that support the findings of this study are openly available (see the Materials and methods section for the details) (Smith et al., 2013; Dong et al., 2020).

\section{Declarations}

Conflicts of interest The authors declare that they have no known competing financial interests or personal relationships that could have appeared to influence the work reported in this paper.

\section{References}

Aggarwal, G., Lippi, G., Lavie, C. J., Henry, B. M., \& SanchisGomar, F. (2020). Diabetes mellitus association with coronavirus disease 2019 (COVID-19) severity and mortality: A pooled analysis. Journal of Diabetes, 12(11), 851-855. https://doi.org/10.1111/1753-0407.13091

Alexander, J., Tinkov, A., Strand, T. A., Alehagen, U., Skalny, A., \& Aaseth, J. (2020). Early nutritional interventions with Zinc, Selenium and Vitamin D for raising antiviral resistance against progressive COVID-19. Nutrients, 12(8), 2358. https://doi.org/10.3390/nu12082358

Alloway, B. J. (2009). Soil factors associated with zinc deficiency in crops and humans. Environmental Geochemistry and Health, 31(5), 537-548. https://doi.org/10.1007/ s10653-009-9255-4

Al-Salameh, A., Lanoix, J.-P., Bennis, Y., Andrejak, C., Brochot, E., Deschasse, G., et al. (2020). The association between body mass index class and coronavirus disease 2019 outcomes. International Journal of Obesity, 45(3), 700-705. https://doi.org/10.1038/s41366-020-00721-1

Barocas, J. A., So-Armah, K., Cheng, D. M., Lioznov, D., Baum, M., Gallagher, K., et al. (2019). Zinc deficiency and advanced liver fibrosis among HIV and hepatitis C co-infected anti-retroviral naïve persons with alcohol use in Russia. PLoS ONE, 14(6), e0218852. https://doi.org/10. 1371/journal.pone.0218852

Calder, P. C. (2020). Nutrition, immunity and COVID-19. BMJ Nutrition, Prevention \& Health, 3(1), 74-92. https://doi. org/10.1136/bmjnph-2020-000085

Calder, P. C., Carr, A. C., Gombart, A. F., \& Eggersdorfer, M. (2020). Optimal nutritional status for a well-functioning immune system is an important factor to protect against viral infections. Nutrients, 12(4), 1181. https://doi.org/10. 3390/nu12041181

Dinh, Q. T., Cui, Z., Huang, J., Tran, T. A. T., Wang, D., Yang, W., et al. (2018). Selenium distribution in the 
Chinese environment and its relationship with human health: A review. Environment International, 112, 294309. https://doi.org/10.1016/j.envint.2017.12.035

Dong, E., Du, H., \& Gardner, L. (2020). An interactive webbased dashboard to track COVID-19 in real time. The Lancet Infectious Diseases, 20(5), 533-534. https://doi. org/10.1016/S1473-3099(20)30120-1

Gashu, D., Nalivata, P. C., Amede, T., Ander, E. L., Bailey, E. H., Botoman, L., et al. (2021). The nutritional quality of cereals varies geospatially in Ethiopia and Malawi. Nature, 594(7861), 71-76. https://doi.org/10.1038/ s41586-021-03559-3

Gonçalves, T. J. M., Gonçalves, S. E. A. B., Guarnieri, A., Risegato, R. C., Guimarães, M. P., de Freitas, D. C., et al. (2021). Association Between Low Zinc Levels and Severity of Acute Respiratory Distress Syndrome by New Coronavirus SARS-CoV-2. Nutrition in Clinical Practice: Official Publication of the American Society for Parenteral and Enteral Nutrition, 36(1), 186-191. https://doi.org/10.1002/ncp.10612

Heller, R. A., Sun, Q., Hackler, J., Seelig, J., Seibert, L., Cherkezov, A., et al. (2021). Prediction of survival odds in COVID-19 by zinc, age and selenoprotein P as composite biomarker. Redox Biology, 38, 101764. https:// doi.org/10.1016/j.redox.2020.101764

Holman, N., Knighton, P., Kar, P., O'Keefe, J., Curley, M., Weaver, A., et al. (2020). Risk factors for COVID-19-related mortality in people with type 1 and type 2 diabetes in England: A population-based cohort study. The Lancet. Diabetes \& Endocrinology, 8(10), 823-833. https:// doi.org/10.1016/S2213-8587(20)30271-0

Im, J. H., Je, Y. S., Baek, J., Chung, M.-H., Kwon, H. Y., \& Lee, J.-S. (2020). Nutritional status of patients with COVID-19. International Journal of Infectious Diseases: IJID: Official Publication of the International Society for Infectious Diseases, 100, 390-393. https:// doi.org/10.1016/j.ijid.2020.08.018

Johnson, C. C., Fordyce, F. M., \& Rayman, M. P. (2010). Symposium on Geographical and geological influences on nutritio Factors controlling the distribution of selenium in the environment and their impact on health and nutrition Conference on 'Over and undernutrition challenges and approaches. Proceedings of the Nutrition Society 69(1), 119-132.

Jothimani, D., Kailasam, E., Danielraj, S., Nallathambi, B., Ramachandran, H., Sekar, P., et al. (2020). COVID-19: Poor outcomes in patients with zinc deficiency. International Journal of Infectious Diseases: IJID: Official Publication of the International Society for Infectious Diseases, 100, 343-349. https://doi.org/10.1016/j.ijid. 2020.09.014

Lassale, C., Gaye, B., Hamer, M., Gale, C. R., \& Batty, G. D. (2020). Ethnic disparities in hospitalisation for COVID19 in England: The role of socioeconomic factors, mental health, and inflammatory and pro-inflammatory factors in a community-based cohort study. Brain, Behavior, and Immunity, 88, 44-49. https://doi.org/10.1016/j.bbi.2020. 05.074

Liu, Q., Zhao, X., Ma, J., Mu, Y., Wang, Y., Yang, S., et al. (2021). Selenium (Se) plays a key role in the biological effects of some viruses: Implications for COVID-19.
Environmental Research, 196, 110984. https://doi.org/10. 1016/j.envres.2021.110984

Moghaddam, A., Heller, R. A., Sun, Q., Seelig, J., Cherkezov, A., Seibert, L., et al. (2020). Selenium deficiency is associated with mortality risk from COVID-19. Nutrients, 12(7), 2098. https://doi.org/10.3390/nu12072098

Modern Epidemiology. (2020). https://www.ovid.com/productdetails.4634.html. Accessed 30 Nov 2020.

Nai, A., Lorè, N. I., Pagani, A., De Lorenzo, R., Di Modica, S., Saliu, F., et al. (2021). Hepcidin levels predict Covid-19 severity and mortality in a cohort of hospitalized Italian patients. American Journal of Hematology, 96(1), E32E35. https://doi.org/10.1002/ajh.26027

Park, S. K., Sack, C., Sirén, M. J., \& Hu, H. (2020). Environmental cadmium and mortality from influenza and pneumonia in US Adults. Environmental Health Perspectives, 128(12), 127004. https://doi.org/10.1289/EHP7598

Pepper, I. L. (2013). The Soil Health-Human Health Nexus. Critical Reviews in Environmental Science and Technology, 43(24), 2617-2652. https://doi.org/10.1080/10643 389.2012.694330

Perricone, C., Bartoloni, E., Bursi, R., Cafaro, G., Guidelli, G. M., Shoenfeld, Y., \& Gerli, R. (2020). COVID-19 as part of the hyperferritinemic syndromes: The role of iron depletion therapy. Immunologic Research, 68(4), 213224. https://doi.org/10.1007/s12026-020-09145-5

Raha, S., Mallick, R., Basak, S., \& Duttaroy, A. K. (2020). Is copper beneficial for COVID-19 patients? Medical Hypotheses, 142, 109814. https://doi.org/10.1016/j.mehy. 2020.109814

Scientific Opinion on the substantiation of health claims related to copper and reduction of tiredness and fatigue (ID 272), maintenance of the normal function of the nervous system (ID 1723), maintenance of the normal function of the immune system (ID 1725) and contribution to normal energy-yielding metabolism (ID 1729) pursuant to Article 13(1) of Regulation (EC) No 1924/2006. (n.d.). EFSA Journal, (2011;9(4):2079). https://doi.org/10.2903/j.efsa. 2011.2079

Scientific Opinion on the substantiation of health claims related to iron and formation of red blood cells and haemoglobin (ID 249, ID 1589), oxygen transport (ID 250, ID 254, ID 256), energy-yielding metabolism (ID 251, ID 1589), function of the immune system (ID 252, ID 259), cognitive function (ID 253) and cell division (ID 368) pursuant to Article 13(1) of Regulation (EC) No 1924/2006. (n.d.). EFSA Journal, (2009; 7(9):1215). https://doi.org/ 10.2903/j.efsa.2009.1215

Scientific Opinion on the substantiation of health claims related to zinc and function of the immune system (ID 291, 1757), DNA synthesis and cell division (ID 292, 1759), protection of DNA, proteins and lipids from oxidative damage (ID 294, 1758), maintenance of bone (ID 295, 1756), cognitive function (ID 296), fertility and reproduction (ID 297, 300), reproductive development (ID 298), muscle function (ID 299), metabolism of fatty acids (ID 302), maintenance of joints (ID 305), function of the heart and blood vessels (ID 306), prostate function (ID 307), thyroid function (ID 308), acid-base metabolism (ID 360), vitamin A metabolism (ID 361) and maintenance of vision (ID 361) pursuant to Article 13(1) of Regulation (EC) 
No 1924/2006. (n.d.). EFSA Journal, (2009; 7(9):1229). https://doi.org/10.2903/j.efsa.2009.1229

Scientific Opinion on the substantiation of health claims related to copper and protection of DNA, proteins and lipids from oxidative damage (ID 263, 1726), function of the immune system (ID 264), maintenance of connective tissues (ID 265, 271, 1722), energy-yielding metabolism (ID 266), function of the nervous system (ID 267), maintenance of skin and hair pigmentation (ID 268, 1724), iron transport (ID 269, 270, 1727), cholesterol metabolism (ID 369), and glucose metabolism (ID 369) pursuant to Article 13(1) of Regulation (EC) No 1924/2006. (n.d.). EFSA Journal, https://doi.org/10.2903/j.efsa.2009.1211

Scientific Opinion on the substantiation of health claims related to selenium and protection of DNA, proteins and lipids from oxidative damage (ID 277, 283, 286, 1289, $1290,1291,1293,1751)$, function of the immune system (ID 278), thyroid function (ID 279, 282, 286, 1289, 1290, 1291, 1293), function of the heart and blood vessels (ID 280), prostate function (ID 284), cognitive function (ID 285) and spermatogenesis (ID 396) pursuant to Article 13(1) of Regulation (EC) No 1924/2006. (n.d.). EFSA Journal, (2009; 7(9):1220). https://doi.org/10.2903/j.efsa. 2009.1220

Shakoor, H., Feehan, J., Al Dhaheri, A. S., Ali, H. I., Platat, C., Ismail, L. C., et al. (2021). Immune-boosting role of vitamins D, C, E, zinc, selenium and omega-3 fatty acids: Could they help against COVID-19? Maturitas, 143, 1-9. https://doi.org/10.1016/j.maturitas.2020.08.003

Smith, D. B., Smith, S. M., \& Horton, J. D. (2013). History and evaluation of national-scale geochemical data sets for the United States. Geoscience Frontiers, 4(2), 167-183. https://doi.org/10.1016/j.gsf.2012.07.002

Sonnweber, T., Boehm, A., Sahanic, S., Pizzini, A., Aichner, M., Sonnweber, B., et al. (2020). Persisting alterations of iron homeostasis in COVID-19 are associated with non-resolving lung pathologies and poor patients' performance: A prospective observational cohort study. Respiratory Research, 21(1), 276. https://doi.org/10.1186/ s12931-020-01546-2

Stata Bookstore I Spatial Autoregressive Models Reference Manual, Release 16. (2020). https://www.stata.com/books tore/spatial-autoregressive-models-reference-manual/. Accessed 2 Dec 2020.

Steffan, J. J., Brevik, E. C., Burgess, L. C., \& Cerdà, A. (2018). The effect of soil on human health: An overview. European Journal of Soil Science, 69(1), 159-171. https://doi. org/10.1111/ejss.12451

Taneri, P. E., Gómez-Ochoa, S. A., Llanaj, E., Raguindin, P. F., Rojas, L. Z., Roa-Díaz, Z. M., et al. (2020). Anemia and iron metabolism in COVID-19: A systematic review and meta-analysis. European Journal of Epidemiology, 35(8), 763-773. https://doi.org/10.1007/s10654-020-00678-5

Thomas, S., Patel, D., Bittel, B., Wolski, K., Wang, Q., Kumar, A., et al. (2021). Effect of High-Dose Zinc and Ascorbic Acid Supplementation vs Usual Care on Symptom Length and Reduction Among Ambulatory Patients With SARSCoV-2 Infection: The COVID A to $\mathrm{Z}$ Randomized Clinical Trial. JAMA Network Open, 4(2), e210369. https://doi. org/10.1001/jamanetworkopen.2021.0369
USDA ERS - Rural-Urban Continuum Codes. (2021). https:// www.ers.usda.gov/data-products/rural-urban-continuumcodes.aspx. Accessed 11 April 2021.

Vogel-González, M., Talló-Parra, M., Herrera-Fernández, V., Pérez-Vilaró, G., Chillón, M., Nogués, X., et al. (2021). Low zinc levels at admission associates with poor clinical outcomes in SARS-CoV-2 Infection. Nutrients, 13(2), 562. https://doi.org/10.3390/nu13020562

Williamson, E. J., Walker, A. J., Bhaskaran, K., Bacon, S., Bates, C., Morton, C. E., et al. (2020). Factors associated with COVID-19-related death using OpenSAFELY. Nature, 584(7821), 430-436. https://doi.org/10.1038/ s41586-020-2521-4

Wintergerst, E. S., Maggini, S., \& Hornig, D. H. (2006). Immune-Enhancing Role of Vitamin $\mathrm{C}$ and Zinc and Effect on Clinical Conditions. Annals of Nutrition and Metabolism, 50(2), 85-94. https://doi.org/10.1159/00009 0495

Yao, J. S., Paguio, J. A., Dee, E. C., Tan, H. C., Moulick, A., Milazzo, C., et al. (2021). The Minimal Effect of Zinc on the Survival of Hospitalized Patients With COVID-19: An Observational Study. Chest, 159(1), 108-111. https://doi. org/10.1016/j.chest.2020.06.082

Yasui, Y., Yasui, H., Suzuki, K., Saitou, T., Yamamoto, Y., Ishizaka, T., et al. (2020). Analysis of the predictive factors for a critical illness of COVID-19 during treatment - relationship between serum zinc level and critical illness of COVID-19. International Journal of Infectious Diseases: IJID: Official Publication of the International Society for Infectious Diseases, 100, 230-236. https://doi. org/10.1016/j.ijid.2020.09.008

Yehia, B. R., Winegar, A., Fogel, R., Fakih, M., Ottenbacher, A., Jesser, C., et al. (2020). Association of Race With Mortality Among Patients Hospitalized With Coronavirus Disease 2019 (COVID-19) at 92 US Hospitals. JAMA Network Open, 3(8), e2018039. https://doi.org/10.1001/ jamanetworkopen.2020.18039

Yuan, L., Ma, Z. F., Zhang, M., Qin, L., Yin, X., \& Han, F. (2022). Hair SE is a sensitive biomarker to monitor the effects of SE supplementation in elderly. Biological Trace Element Research, 200, 88-496. https://doi.org/10.1007/ s12011-021-02674-6

Zhang, X., Wang, T., Li, S., Ye, C., Hou, J., Li, Q., et al. (2019). A Spatial Ecology Study of Keshan Disease and Hair Selenium. Biological Trace Element Research, 189(2), 370-378. https://doi.org/10.1007/s12011-018-1495-7

Zhang, J., Taylor, E. W., Bennett, K., Saad, R., \& Rayman, M. P. (2020). Association between regional selenium status and reported outcome of COVID-19 cases in China. The American Journal of Clinical Nutrition, 111(6), 12971299. https://doi.org/10.1093/ajcn/nqaa095

Zhou, H., Wang, T., Li, Q., \& Li, D. (2018). Prevention of Keshan Disease by Selenium Supplementation: A Systematic Review and Meta-analysis. Biological Trace Element Research, 186(1), 98-105. https://doi.org/10.1007/ s12011-018-1302-5

Zhou, C., Chen, Y., Ji, Y., He, X., \& Xue, D. (2020a). Increased serum levels of hepcidin and ferritin are associated with severity of COVID 19. Medical Science Monitor, 26, e926178. https://doi.org/10.12659/MSM.926178 
Zhou, F., Yu, T., Du, R., Fan, G., Liu, Y., Liu, Z., et al. (2020b). Clinical course and risk factors for mortality of adult inpatients with COVID-19 in Wuhan, China: A retrospective cohort study. Lancet (London, England), 395(10229), 1054-1062.

30566-3
Publisher's Note Springer Nature remains neutral with regard to jurisdictional claims in published maps and institutional affiliations. 